\title{
Plankton distribution and activity in the North Sea/Skagerrak-Kattegat frontal area in April 1984
}

\author{
K. Richardson \\ Danish Institute of Fisheries and Marine Research, Charlottenlund Castle, DK-2920 Charlottenlund, Denmark
}

\begin{abstract}
Northwest Danish coast were sampled systematically and repeatedly between 5 and 14 April 1984, for distribution of temperature, salinity, and chlorophyll $a$ fluorescence throughout the water column. Low chlorophyll concentrations were recorded at stations in North Sea water. In the Skagerrak/Kattegat stations sampled, dense phytoplankton concentrations (chl $a$ up to $>20 \mathrm{mg} \mathrm{m}^{-3}$ ) were observed in association with a strong halocline (surface to bottom $\Delta \mathrm{S}$ up to $>15 \%$ o. This halocline weakened somewhat in the region north/northeast of Skagen and at 'upwelling' stations near the Swedish coast. Surface patches of elevated chlorophyll concentrations were frequently associated with these weakenings of the halocline. Determination of combined nitrite/ nitrate revealed elevated values in surface waters in these less stratified regions. A strong front occurred in the approaches toward North Sea water to the west of Skagen. Over the frontal region, the water column salinity difference decreased from $>12$ to $<0.1 \%$ over the course of $39 \mathrm{~km}$. The distribution of chlorophyll in relation to the hydrographic features of this front was determined 4 times during $1 \mathrm{wk}$. Chlorophyll distribution patterns were apparently related to hydrographic features and were observed to be extremely dynamic. Primary production and light measurements were taken on 1 frontal crossing. These indicate that daily production rates may have been on the order of $25 \times$ higher in this frontal region than in surrounding waters at the time of sampling. Copepod nauplii and egg distributions were ca $10 \times$ higher in Skagerrak/Kattegat waters than in the North Sea and did not show a clear association with the front. The highest nauplii/egg concentrations were observed in association with dense chlorophyll patches located at the pycnocline. Egg production rates of the copepod Calanus finmarchicus were shown to be positively correlated with chlorophyll concentration at the depth of collection.
\end{abstract}

\section{INTRODUCTION}

Transition or boundary zones between different water masses ('fronts') are being increasingly implicated as important to various fisheries (e.g. Fournier 1978, Mills \& Fournier 1979). However, the biological processes occurring in frontal regions are, as yet, not well understood. Although a number of workers have reported increased concentrations of phyto/zooplankton near thermal and salinity fronts (e.g. Pingree et al. 1975, Holligan \& Harbour 1976, Savidge 1976, Fournier et al. 1977, Simpson et al. 1978, Fournier et al. 1979, Holligan 1979, Floodgate et al. 1981, Seliger et al. 1981, Beardall et al. 1982, Simpson et al. 1982), it is still unclear to what degree these plankton patches result from in situ production and/or unspecified physical concentration processes. One difficulty in differentiating between physical and biological effects occurring at fronts is the lack of good time series data relating to biological processes in such regions; many reports of elevated plankton concentrations in frontal regions are based on single crossings of a front.

In a systematic coverage of a frontal zone in the western Irish Sea, Richardson et al. (1985) noted that elevated chlorophyll patches were intermittently associated with surface waters near the front during the period of stratification. Analysis of surface water data as a whole revealed significantly more chlorophyll in frontal than in surrounding waters over the seasonal cycle. However, when the chlorophyll present in the upper $30 \mathrm{~m}$ of the water column was averaged, there was no difference between frontal and stratified waters.

Although these observations at a thermal front are not necessarily typical for fronts in general, the transient nature of the chlorophyll patches in surface frontal waters in the Irish Sea study emphasizes the general need for more detailed time series studies of the variability in the distribution of plankton occurring at fronts in order to further understanding of the biologi- 
cal processes occurring in these regions. In particular, there is a need to consider if and/or how the elevated plankton concentrations observed in frontal regions influence higher trophic levels in the same region.

The present study was designed to provide a detailed picture of changes in hydrographic parameters and chlorophyll distribution over a frontal region during a 1 wk period. In addition, during 1 crossing, measurements were made of primary production, inorganic nutrient, particle and microzooplankton distributions in the frontal region. In a preliminary attempt to study the influence of the front on secondary production, the egg production rate of the copepod Calanus finmarchicus collected from stations exhibiting varying chlorophyll a concentrations was measured throughout the study.

The frontal region examined occurs between the North Sea and Skagerrak/Kattegat waters. It is primarily a salinity feature and is permanently present, although its position varies throughout the year and as a function of wind and weather conditions (Svansson 1975, Foyn et al. 1978). This front is of biological and commercial interest in that it has been implicated as a possible focus for larval fish distributions (Christensen et al. 1983) and for the development of blooms of the red-tide dinoflagellate Gyrodinium aureolum which intermittently plague the Scandinavian coast (Richardson \& Kullenberg 1984).

\section{MATERIALS AND METHODS}

The survey was conducted from 4 to 14 April, 1984 aboard the 'R.V. Dana' (Danish Fisheries Ministry). Observations were made at fixed stations on a grid drawn over the waters surrounding Skagen (Fig. 1). Temperature and salinity were profiled using a Neil Brown Mark III CTD System. Fluorescence was recorded using a $Q$ Instruments in situ fluorometer

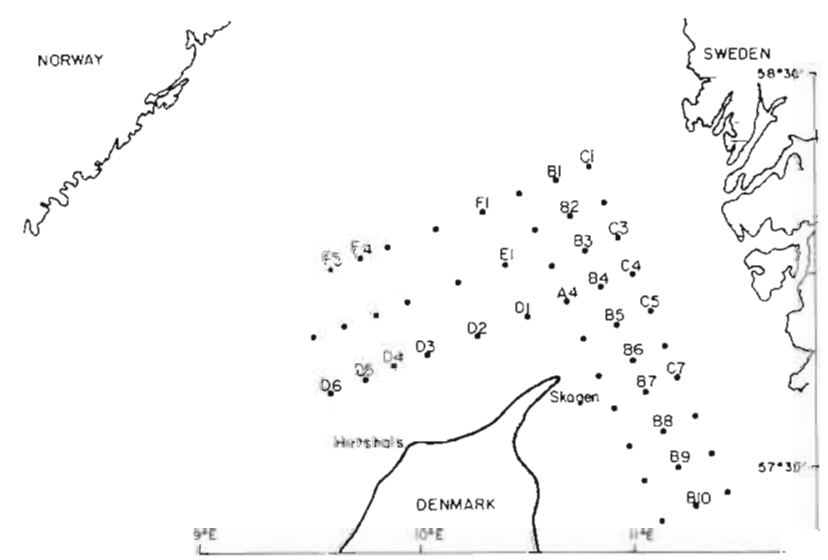

Fig. 1 Approximate positions of stations in the study area. Stations referred to in the text are identified mounted on the CTD system (Hundahl \& Holck 1980). Signals from the fluorometer were fed into the dataretrieving system of the CTD. The interval between data collections was $0.5 \mathrm{~s}$.

Calibration of the fluorometer was made by holding the instrument at a fixed depth while simultaneously pumping $4 \mathrm{l}$ water from the sample depth. An average of the fluorometer readings over the period of water collection was taken to represent the fluorescence of the water sample. Chlorophyll a analysis of the samples was made by filtering onto GFC filters and immediately extracting in $90 \%$ acetone. Chlorophyll a determination with correction for phaeopigments was made spectrophotometrically after the method of Lorenzen (Strickland \& Parsons 1972) with absorption being measured on a Perkin Elmer 554 spectrophotometer. A linear regression was performed relating fluorescence to chl a $\mathrm{l}^{-1}$ from all calibration samples $\left(n=27 ; I^{2}=0.91\right)$. This relation was thereafter used to derive chl a concentrations from fluorescence measurements. Integrated fluorescence/ chlorophyll determinations through the 'euphotic' water column were calculated by taking the average of 1 fluorescence reading from each $1 \mathrm{~m}$ depth interval down to $30 \mathrm{~m}$. For ease of computation, the first reading from each depth interval was used. Nitrate + nitrite was determined on nonfiltered samples after the method described by Grasshoff (1976).

Primary production. Primary productivity determinations were made at 19 stations by collecting 1.51 bottle samples at $3 \mathrm{~m}$ and as close as possible to the subsurface chlorophyll peak. When no subsurface peak was present, the second depth was at either 10 or $20 \mathrm{~m}$ depending on the depth of the surface mixed layer. Samples were kept in subdued light, filtered through a $200 \mu \mathrm{m}$ mesh and transferred to $25 \mathrm{ml}$ acid-washed Pyrex bottles. Four $\mu \mathrm{Ci}$ of a $\mathrm{NaH}^{14} \mathrm{CO}_{3}$ solution were added to each bottle. The ${ }^{14} \mathrm{C}$ addition was checked by taking $50 \mu \mathrm{l}$ subsamples of the incubation media and adding them to $500 \mu \mathrm{l} \beta$ phenylethylamine. These were stored for later counting. Samples were fixed to a rotating wheel and incubated for $2.5 \mathrm{~h}$ at ambient seawater temperature $\pm 2 \mathrm{C}^{\circ}$. Photon flux densities of incubation of samples from each depth were 320 and $12 \mu \mathrm{mol} \mathrm{m} \mathrm{m}^{-2} \mathrm{~s}^{-1}$. Light was measured using a Licor Quantum Radiometer Photometer equipped with a cosine corrected sensor. A formalin-killed control from each depth was also incubated. Details of calculations used in estimating primary production are given in Richardson et al. 1984.

Copepod eggs and nauplii. Samples for determination of the density of copepod eggs and nauplii were taken by means of a submersible pump (capacity $6 \mathrm{I}$ $\mathrm{min}^{-1}$, inner hose diameter $0.6 \mathrm{~cm}$ ). $24 \mathrm{l}$ samples were filtered on a $40 \mu \mathrm{m}$ mesh size sieve, and preserved in 
$4 \%$ borax-buffered formalin. Seven stations on the B and D lines (Fig. 1) were sampled at surface $(3 \mathrm{~m})$, halocline (10 to $22 \mathrm{~m}), 20$ to $35 \mathrm{~m}$, and in the bottom water' (28 to $100 \mathrm{~m}$ ). Copepod eggs and nauplii were subsequently enumerated in the laboratory.

Particle size distribution determinations. Water samples for particle determination were collected using water bottles. Determinations were conducted immediately after collection by counting particles present in a $14.5 \mathrm{ml}$ subsample (total sample volume = $250 \mathrm{ml}$ ) on a Coulter Counter $\mathrm{TA} \mathrm{II}_{\text {; }}$ orifice size = $140 \mu \mathrm{m}$.

Calanus finmarchicus egg production measurements. Zooplankton were collected from discrete depths with an opening-closing $250 \mu \mathrm{m}$ mesh WP2 net (Tranter 1968). The cod-end contents were immediately diluted into sea water from the collection depth.

Adult females of Calanus finmarchicus were sorted from the collected samples. Care was taken to keep the temperature near that at the collection depth during sorting. Animals were incubated in $1130 \mathrm{ml}$ screw cap bottles filled with seawater from the collection depth. The water had previously been screened through an $80 \mu \mathrm{m}$ mesh sieve to remove large zooplankters. Screening removed less than $5 \%$ of the chlorophyll from the water. In each experiment, 3 to 5 control bottles (without animals) and up to 20 experimental bottles were run. Bottles were fixed on a slowly rotating $(0.5$ or $2 \mathrm{rpm})$ wheel in a dimly lit (13L:11D) temperature-controlled room (in situ temperature $\pm 2 \mathrm{C}^{\circ}$ ). Incubations lasted for between 18 and $30 \mathrm{~h}$.

Eggs spawned during incubations were retained on a $40 \mu \mathrm{m}$ mesh sieve and counted. Calanus finmarchicus eat their own eggs which results in fewer eggs per female in bottles with relatively high female densities. This was corrected for by conducting a series of incubations in which the number of females per bottle was varied between 1 and 20 . The number of eggs produced per female was then regressed against female density in each experiment and the ordinate intercept taken as an estimate of specific egg production rate. Corrections were made for eggs removed in water samples for particle and chlorophyll analysis. The methods for collection of zooplankton and determination of egg production rate are described and discussed in greater detail by Kiørboe et al. (1985).

\section{RESULTS}

\section{Hydrography and chlorophyll distributions}

Fig. 2 shows the surface distribution of salinity and chlorophyll over the study area at (Fig. 2a, b) the beginning and (Fig. 2c, d) end of the cruise. In both cases, a strong front separating North Sea water from lower salinity water can be seen west of Skagen. At the end of the cruise, however, no surface water of $\geq 34 \%$ was encountered and an increased area east of the front was covered by water of $<22 \%$ than at the beginning of the cruise. This increase in low salinity water is presumed to represent outflow from the Baltic during this period. Although the tendency is for low salinity water east of the North Sea front, both surveys of the area revealed several patches of higher salinity surface water east of Skagen, especially towards the Swedish coast.

Surface chlorophyll distributions followed much the same pattern as salinity (Fig. 2). Low chlorophyll concentrations were associated with North Sea water and the lowest salinity water east of Skagen. In the regions where low and high salinity water meet, however, elevated chlorophyll was recorded. Thus, high chlorophyll concentrations were found near the North Sea front and in association with the patches of high salinity water found off the Swedish coast. When chlorophyll integrated through the water column to $30 \mathrm{~m}$ is averaged for all stations at the beginning of the cruise $\left(\overline{\mathrm{x}}=1.07 \mathrm{mg} \mathrm{m}^{-3}\right)$ and at the end $(\overline{\mathrm{x}}=2.10$ $\mathrm{mg} \mathrm{m} \mathrm{m}^{-3}$ ), it can be seen that chlorophyll concentration doubled over this area during the period of study.

Fig. 3 shows depth profiles of salinity, temperature, and chlorophyll for the ' $D$ ' line of stations made on 4 different sampling dates. Most notable is the variability in chlorophyll distribution across the frontal region during this time. At the beginning of the sampling (Apr 6), chlorophyll distributions relate clearly to the salinity structure with the densest concentrations found along the halocline and in association with the front (i.e. region with the greatest surface gradient in salinity).

In the data for April 8, the overall characteristics of the water column resemble those of April 6. However the 34.5 and $30 \%$ surface isohalines have moved eastward; the same is true for the 4 and $6^{\circ} \mathrm{C}$ surface isotherms. There was less chlorophyll in surface waters than on the earlier sampling date and the surface peak earlier observed at Stn D1 was no longer recorded. Convolutions have appeared in the pycnocline chlorophyll distribution and a small patch of elevated chlorophyll concentration was recorded at a depth of $35 \mathrm{~m}$ at Stn D3. As on April 6, the most concentrated surface chlorophyll patch was associated with $4{ }^{\circ} \mathrm{C}$ water.

Between April 8 and 10 major changes occurred in the salinity/temperature profiles over this area. The $34.5 \%$ isohaline no longer intersected the surface in the study area. Furthermore, all isohalines from 26 to $30 \%$ moved westward. The survey revealed no $6{ }^{\circ} \mathrm{C}$ surface water. These observations suggest a possible 
westerly flow of surface water from the Skagerrak during this period. This suggestion is supported by the occurrence of a patch of 3 to $4{ }^{\circ} \mathrm{C}$ water at the most westerly station (D6) on April 10. This cold patch was separated from water of a similar temperature by warmer water at D5. Salinity was also lower at D6 than at D5. High chlorophyll concentrations were associated with this patch and also with Stn D4 and D3 which correspond to the frontal region and, again, water of about $4{ }^{\circ} \mathrm{C}$.

On the last day of the survey (April 13) the 32 and $33 \%$ isohalines intersected the surface at points farther west than on any of the earlier sampling days and no $34 \%$ surface water was encountered in the study area. Likewise, the 4 and $6^{\circ} \mathrm{C}$ isotherms no
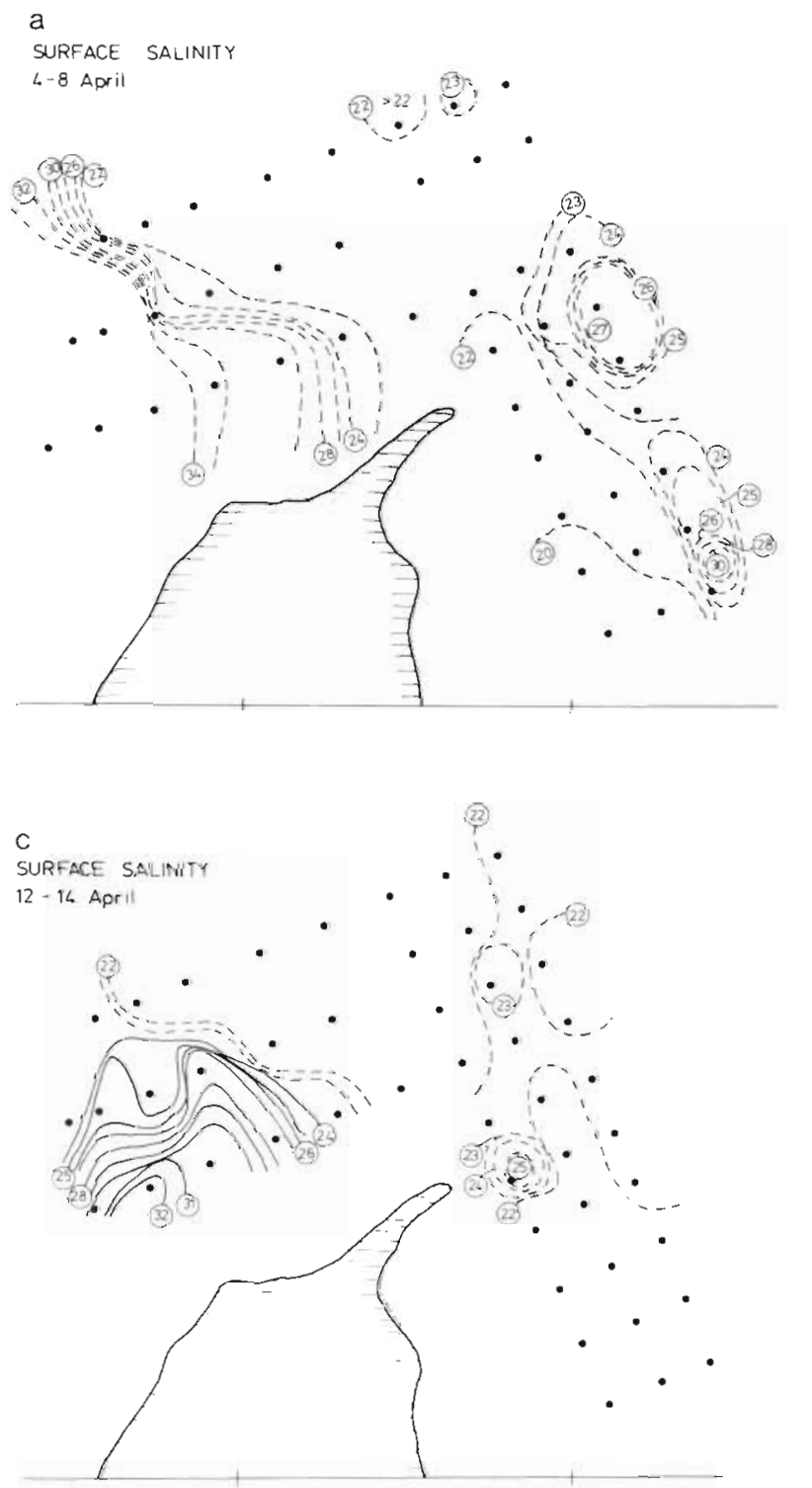

longer intersected the surface within the study area and a large percentage of the area was now covered by water of $\sim 3^{\circ} \mathrm{C}$. Chlorophyll-rich water was more widespread than on the earlier sampling dates; the $3^{\circ} \mathrm{C}$ water was uniformly rich in chlorophyll. In addition, a subsurface fluorescence peak was recorded in the region of the pycnocline (10 to $15 \mathrm{~m}$ depth) at Stn D2 and D3. A separate peak was recorded at 30 to $35 \mathrm{~m}$ at Stn D2 and D1.

Four surveys were also made along the ' $\mathrm{B}$ ' line during this study. The water column in this area was always stratified with respect to salinity and temperature. However, on every sampling occasion, a region experiencing relatively higher surface salinity (and a consequent decrease in the intensity of water column

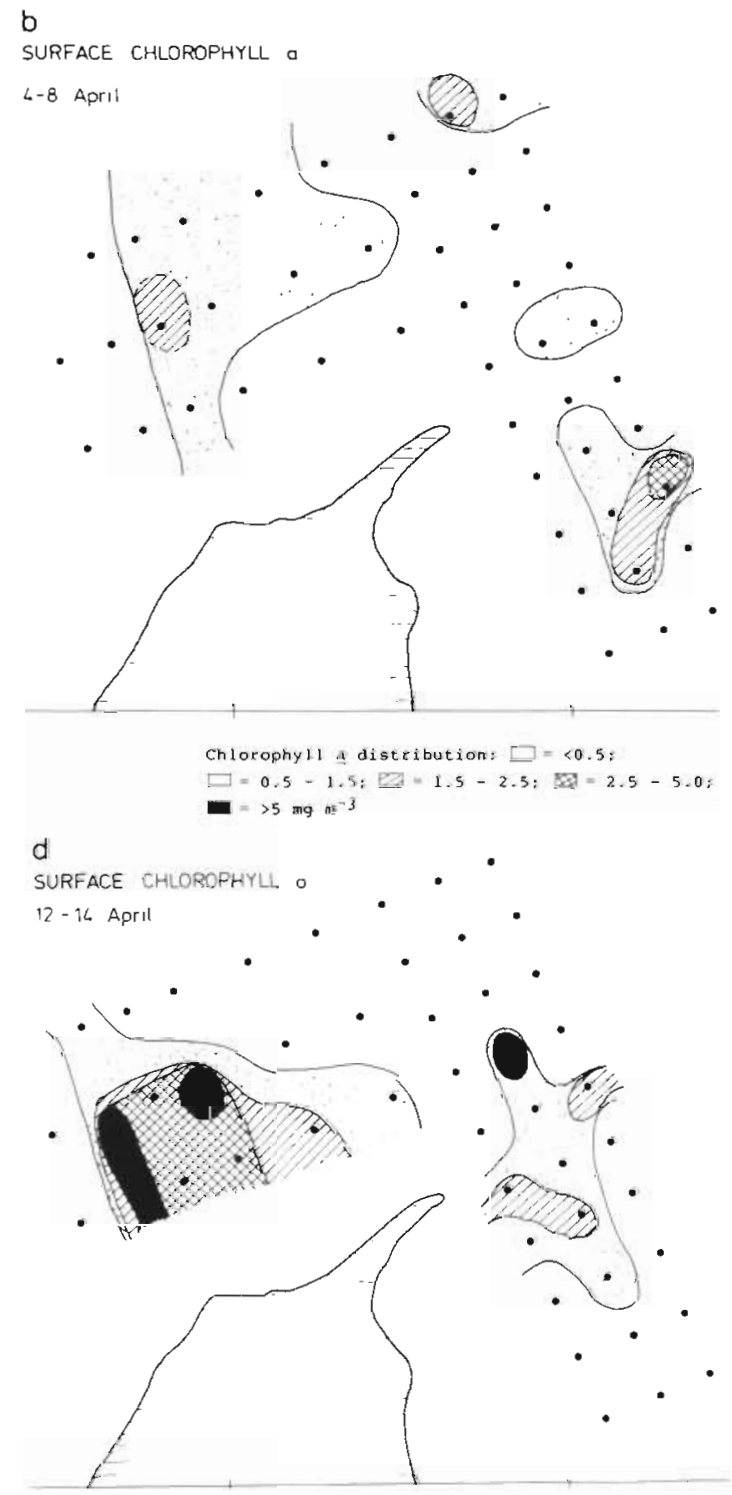

Fig. 2. Surface salinity $(\%)$ and chlorophyll $a$ distributions between 4 and 8 Apr $(a, b)$ and between 12 and 14 Apr (c, d) 
a
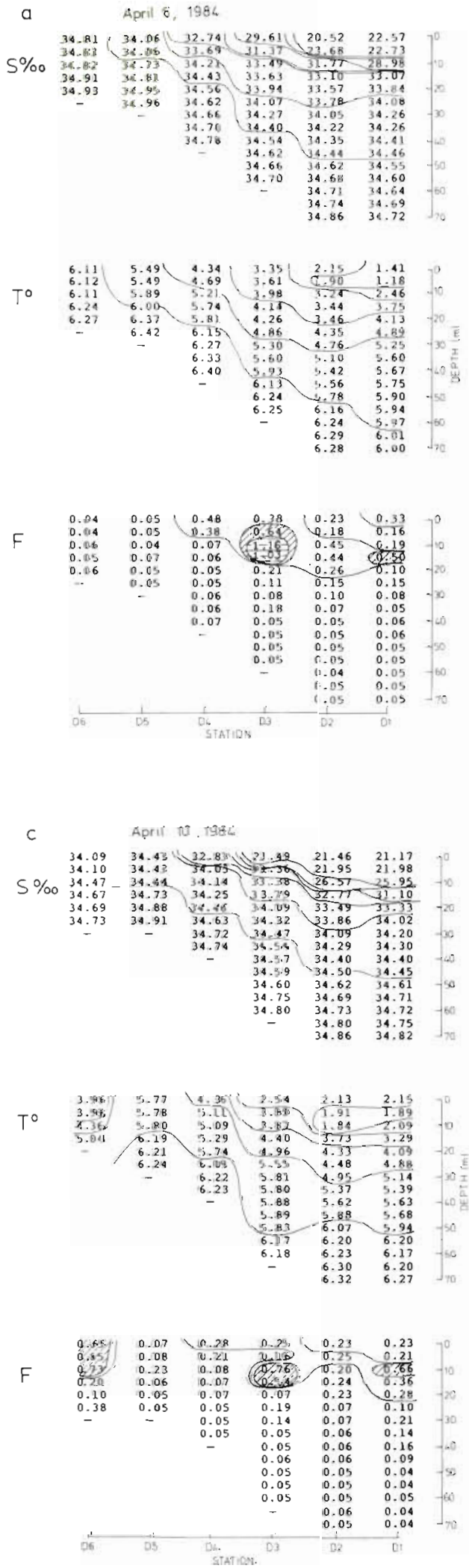
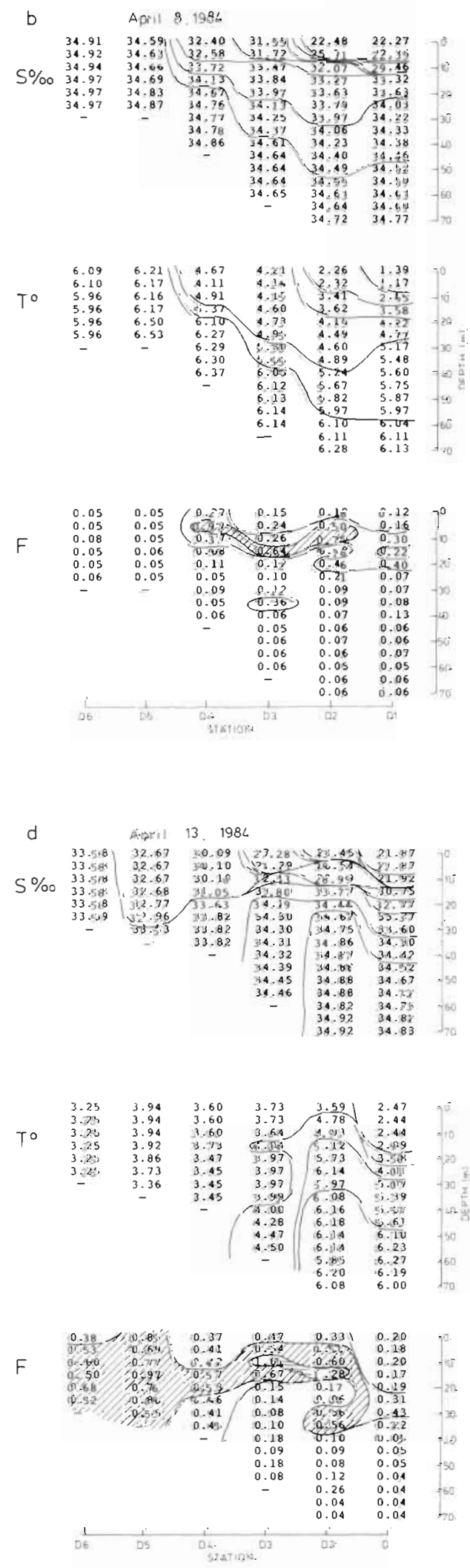

Fig. 3. Salinity $(\%)$, temperature $\left({ }^{\circ} \mathrm{C}\right.$ ) and fluorescence depth profiles for stations on the ' $D$ '-line on (a) Apr 6 , (b) Apr 8 , (c) Apr 10, (d) Apr 13. Fluorescence (F) is expressed in arbitrary units and can be approximately converted to chlorophyll (mg $\mathrm{m}^{-3}$ ) by: fluorescence $=0.109$ chlorophyll $a \pm 0.13$ 
stratification) was observed between Stn B3 and B6. This same region exhibited higher surface chlorophyll concentrations than surrounding waters.

\section{Primary productivity and copepod egg/nauplii distributions}

Fig. 4 shows the distribution of copepod nauplii and eggs, chlorophyll, $\mathrm{NO}_{2}+\mathrm{NO}_{3}$ and primary production over the ' $\mathrm{D}$ ' line on 8 April. Low primary productivity and nauplii/egg concentrations were associated with the North Sea water. Nauplii/egg concentrations were an order of magnitude higher east of the front. Although the limited sampling does not allow good mapping of copepod nauplii/egg distributions, the highest nauplii concentrations seem to be associated in or over pycnocline phytoplankton patches. The same pattern was also observed on the April 7 survey of the 'B' line of stations (Fig. 5).

$\mathrm{NO}_{2}+\mathrm{NO}_{3}$ concentrations were highest in the dense chlorophyll patch located in subsurface waters near the front on April 8 (Fig. 4). However, it should be noted that the nutrient method used does not differentiate between dissolved and particulate inorganic nutrient. Therefore these elevated nutrient values may reflect the high algal biomass in this area. High nutrient concentrations were recorded in subsurface stratified waters and in the waters to the west of the front. Striking are the low $\mathrm{NO}_{2}+\mathrm{NO}_{3}$ values recorded
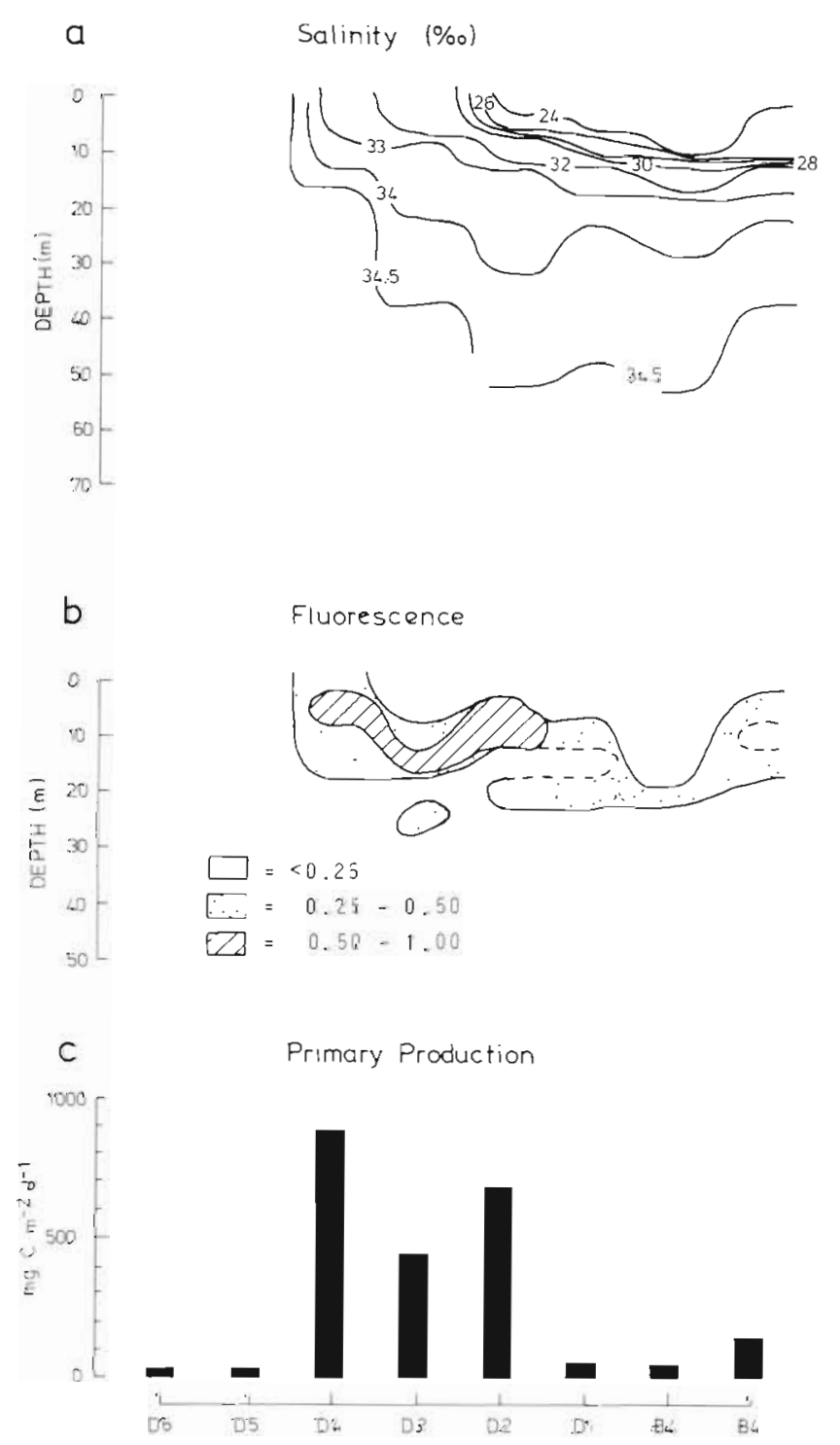

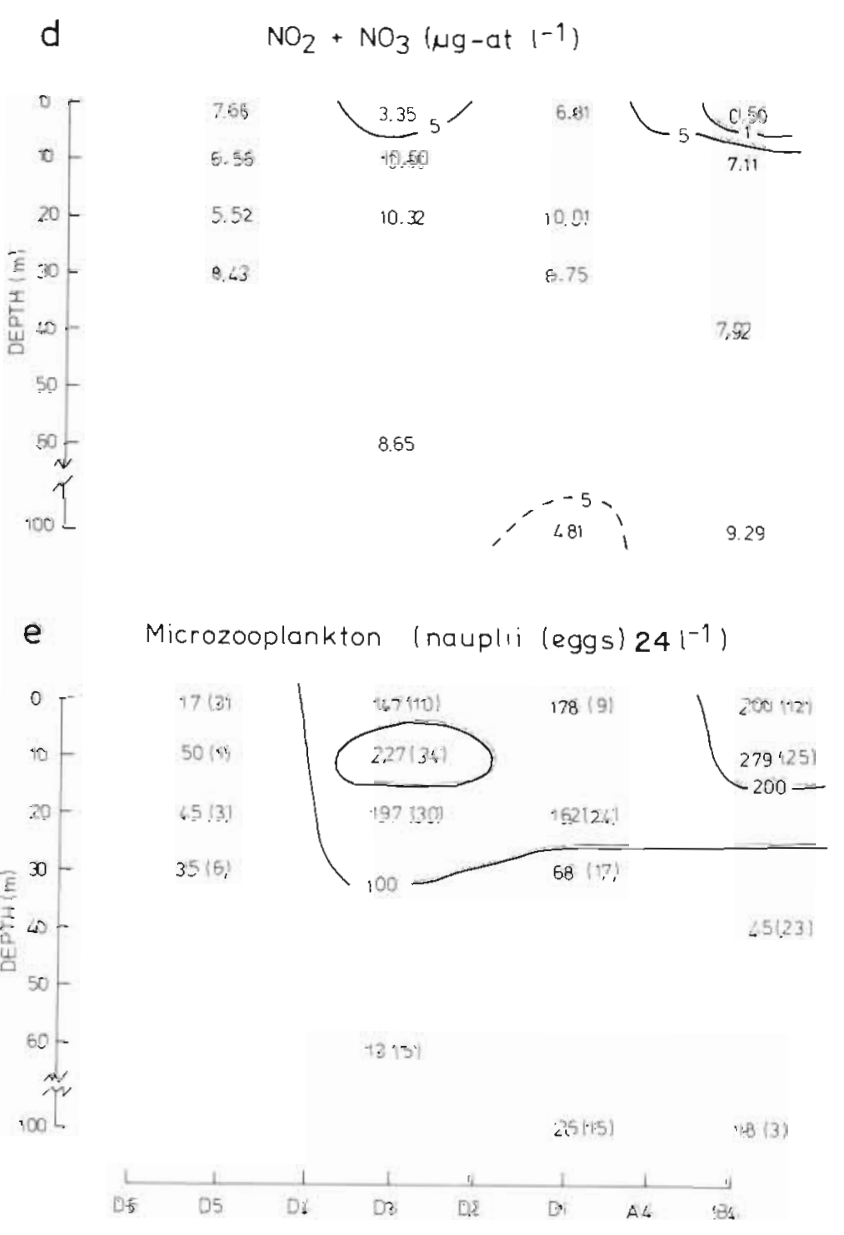

Fig. 4. (a) Salinity, (b) fluorescence, (c) primary production, (d) nitrite + nitrate, (e) microzooplankton (copepod nauplii/eggs) along the ' $D$ ' line on Apr 8 . Stn B4 was sampled on Apr 7. Fluorescence expressed as in Fig. 3 


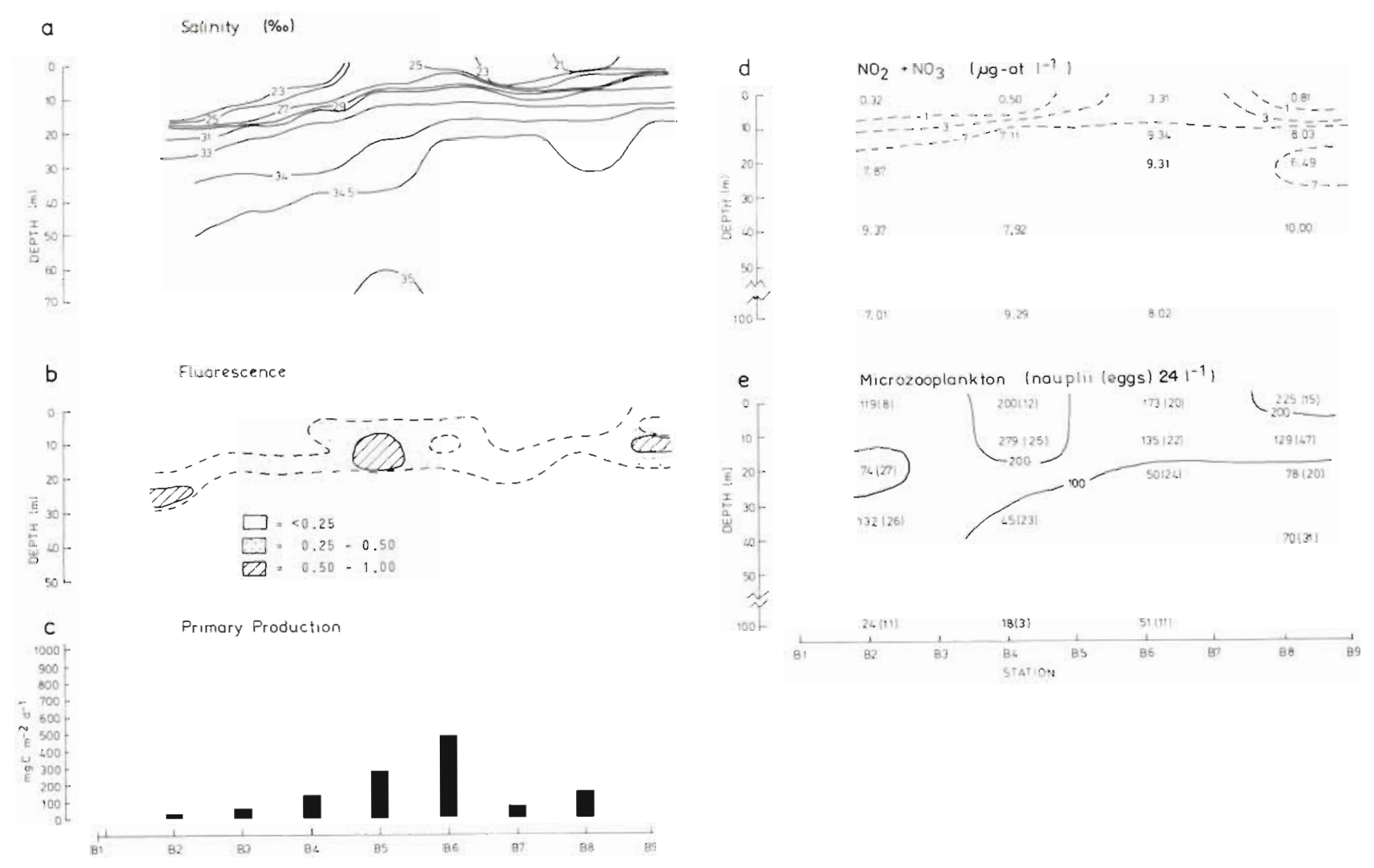

Fig. 5. (a) Salinity, (b) fluorescence, (c) primary production, (d) nitrite + nitrate, (e) microzooplankton along the 'B' line on Apr 7 Fluorescence expressed as in Fig. 3

in the surface stratified waters except at $\operatorname{Stn} B 6$ in a patch of high salinity water.

Estimated daily primary production rates indicate that the frontal region may have been on the order of $25 \times$ more productive than the surrounding waters at this time. Marginally elevated primary production rates were also calculated for Stn B4 to B6 on April 7. From the salinity survey of the ' $\mathrm{B}$ ' line (Fig. 5), it can be seen that these stations bordered a high-surface-salin-ity patch accompanied by elevated surface concentrations of $\mathrm{NO}_{2}+\mathrm{NO}_{3}$, which may account for the increased calculated primary production

On average, the ${ }^{14} \mathrm{C}$ which passed through a $3 \mu \mathrm{m}$ filter and was retained by a $0.22 \mu \mathrm{m}$ filter was less than $10 \%$ over the entire study area. However, at 2 stations this fraction consisted up to $40 \%$ of the total ${ }^{14} \mathrm{C}$ fixed (Stn B2 and C1). Fig. 6 shows the assimilation index (units carbon fixed per unit chlorophyll $a \mathrm{~h}^{-1}$ ) for surface samples (a) and surface salinity contours (b) for the period of 7 to 10 April. The assimilation index was highest at North Sea frontal stations and in the less strongly stratified patches in the water to the east of the front.

\section{Particle size distributions across the front}

To the east of the front, particle concentrations (Estimated Spherical Diameter, ESD, ca 2.5 to $50 \mu \mathrm{m}$ ) were markedly higher in surface waters than at the pycnocline, and a greater percentage of the total volume of particles was made up by small particles in the surface waters than at depth (Table 1). In the frontal stations, the particle size distributions were dominated both in the surface and at depth by a 'top' representing particles between ca 10 to $15 \mu \mathrm{m}$ ESD. West of the front (Stn D6) very small particles dominated in surface waters whereas the 10 to $15 \mu \mathrm{m}$ 'top' was observed in the samples taken from $10 \mathrm{~m}$

\section{Egg production by Calanus finmarchicus}

In Fig. 7, the specific egg production rate of Calanus finmarchicus is plotted against the average chlorophyll a content of the water from which specimens were collected. The assumed boundaries for the water mass of collection were taken from the physical 

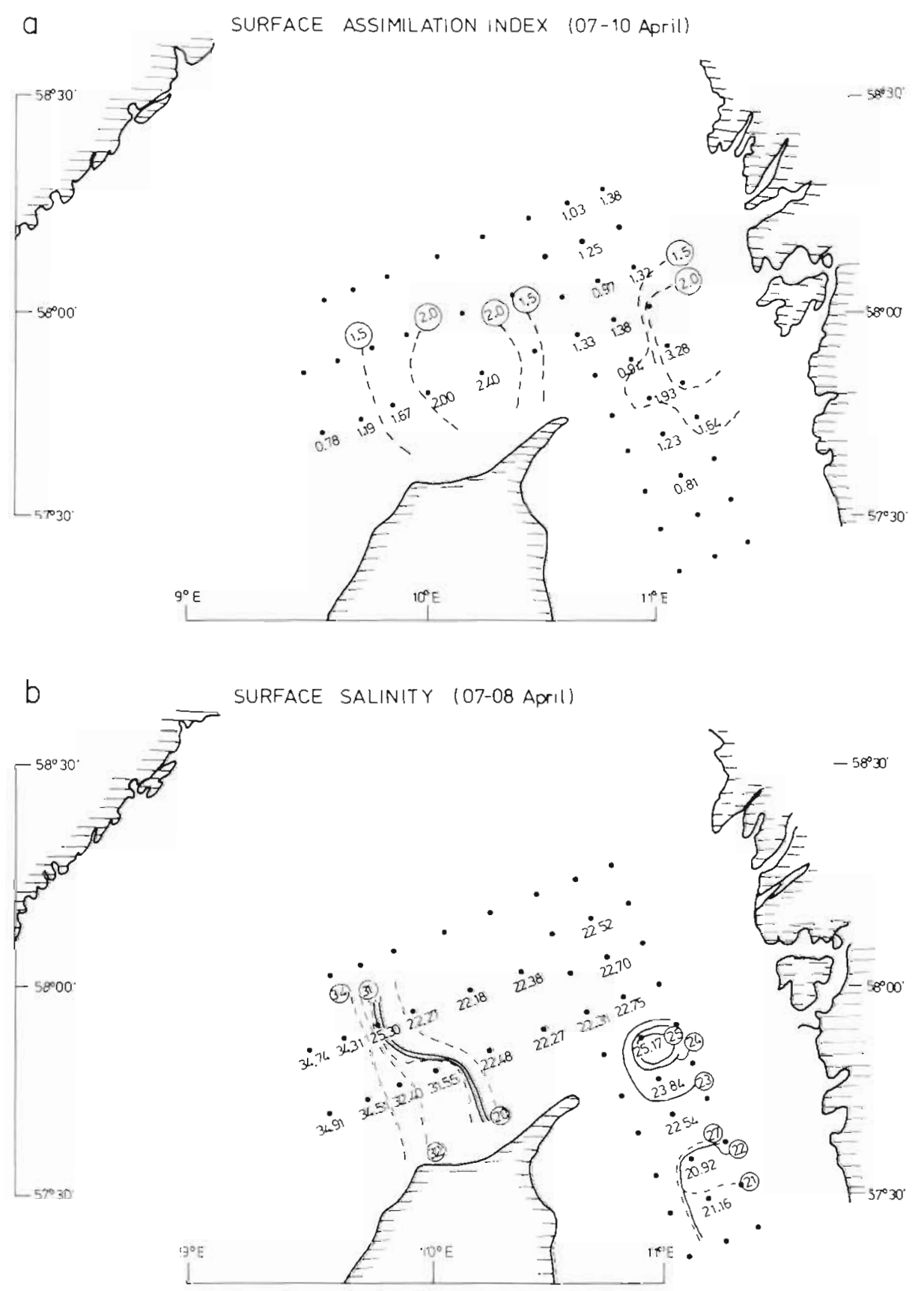

Fig. 6. (a) Assimilation index ( $\mu \mathrm{g}$ $\mathrm{C}$ fixed $[\mu \mathrm{g} \mathrm{chl} a]^{-1} \mathrm{~h}^{-1}$ ) of surface phytoplankton samples. Stations on ' $B$ ' line sampled Apr $\bar{T} ;$ on ' $D$ ' line, Apr 8; on ' $C$ ' line, Apr 10. (b) Surface salinity distributions on Apr 7-8

characteristics of the water column. Fluorescence readings were averaged and converted to chlorophyll for all depths contiguous with the collection depth that exhibited a salinity within $\pm 0.5 \%$ of that at the collection depth. The stations, collection depths and depth intervals over which fluorescence was averaged are presented in Table 2.

Average values of $<1$ to 17.9 eggs female ${ }^{-1} \mathrm{~d}^{-1}$ were recorded over the study area with the highest values being recorded from waters with the greatest concentrations of in situ chlorophyll a.

\section{DISCUSSION AND CONCLUSIONS}

The distribution pattern of chlorophyll a was shown to be highly variable over the study area during this spring survey. In general, however, elevated chlorophyll concentrations were observed in surface waters in the vicinity of the front separating high salinity North Sea water from salinity-stratified waters to the east. Patches of elevated chlorophyll in surface waters were also located in the stratified waters along the Swedish coast. In most cases, these patches were 
Table 1. Particle concentrations and size distributions, in surface waters and at depth, along the ' $\mathrm{D}$ ' line, 8 April

\begin{tabular}{|c|c|c|c|c|}
\hline Station & $\begin{array}{l}\text { Depth } \\
\text { m }\end{array}$ & $\begin{array}{c}\text { Particles } \\
\text { (ESD } 2.5 \text { to } 50 \mu \mathrm{m}) \\
\mathrm{ml}^{-1}\end{array}$ & $\begin{array}{l}\text { Volume of particles } \\
\qquad \mu \mathrm{m}^{3} \mathrm{ml}^{-1}\end{array}$ & $\begin{array}{l}\text { Volume peak } \\
(\% \text { of total) }\end{array}$ \\
\hline $\mathrm{A} 4$ & $\begin{array}{r}3 \\
10\end{array}$ & $\begin{array}{l}6244 \\
4080\end{array}$ & $\begin{array}{l}552819 \\
475655\end{array}$ & $\begin{array}{l}\text { ESD } \quad 4 \mu \mathrm{m}(10 \%) \\
\text { ESD } 10 \mu \mathrm{m}(14 \%)\end{array}$ \\
\hline D1 & $\begin{array}{r}3 \\
20\end{array}$ & $\begin{array}{r}13903 \\
3746\end{array}$ & $\begin{array}{l}922385 \\
475961\end{array}$ & $\begin{array}{l}\mathrm{ESD} \quad 4 \mu \mathrm{m}(12 \%) \\
\mathrm{ESD} 25 \mu \mathrm{m}(17 \%)\end{array}$ \\
\hline $\mathrm{D} 2$ & $\begin{array}{r}3 \\
20\end{array}$ & $\begin{array}{l}8307 \\
6309\end{array}$ & $\begin{array}{l}1216166 \\
1211675\end{array}$ & $\begin{array}{ll}\text { ESD } & 12 \mu \mathrm{m}(15 \%) \\
\mathrm{ESD} & 12 \mu \mathrm{m}(20 \%)\end{array}$ \\
\hline D3 & $\begin{array}{c}3 \\
12.5\end{array}$ & $\begin{array}{l}6195 \\
6660\end{array}$ & $\begin{array}{r}1024273 \\
852971\end{array}$ & $\begin{array}{ll}\text { ESD } & 12 \mu \mathrm{m}(19 \%) \\
\text { ESD } & 12 \mu \mathrm{m}(12 \%)\end{array}$ \\
\hline D4 & $\begin{array}{c}3 \\
12.5\end{array}$ & $\begin{array}{l}4936 \\
7664\end{array}$ & $\begin{array}{l}1032557 \\
2612981\end{array}$ & $\begin{array}{ll}\text { ESD } & 12 \mu \mathrm{m}(16 \%) \\
\text { ESD } & 12 \mu \mathrm{m}(27 \%)\end{array}$ \\
\hline D5 & $\begin{array}{l}3 \\
7.5\end{array}$ & $\begin{array}{l}3465 \\
1976\end{array}$ & $\begin{array}{l}352221 \\
269467\end{array}$ & $\begin{array}{ll}\text { ESD } & 12 \mu \mathrm{m}(17 \%) \\
\text { ESD } & 12 \mu \mathrm{m}(16 \%)\end{array}$ \\
\hline D6 & $\begin{array}{r}3 \\
10\end{array}$ & $\begin{array}{l}8245 \\
8548\end{array}$ & $\begin{array}{l}326531 \\
588436\end{array}$ & $\begin{array}{l}\text { ESD } 2.5 \mu \mathrm{m}(17 \%) \\
\operatorname{ESD} 12 \mu \mathrm{m}(19 \%)\end{array}$ \\
\hline
\end{tabular}

Fig. 7. Calanus finmarchicus egg production rate expressed as a function of chlorophyll concentration at the collection depth. Letters and numbers refer to stations where plankton collection took place

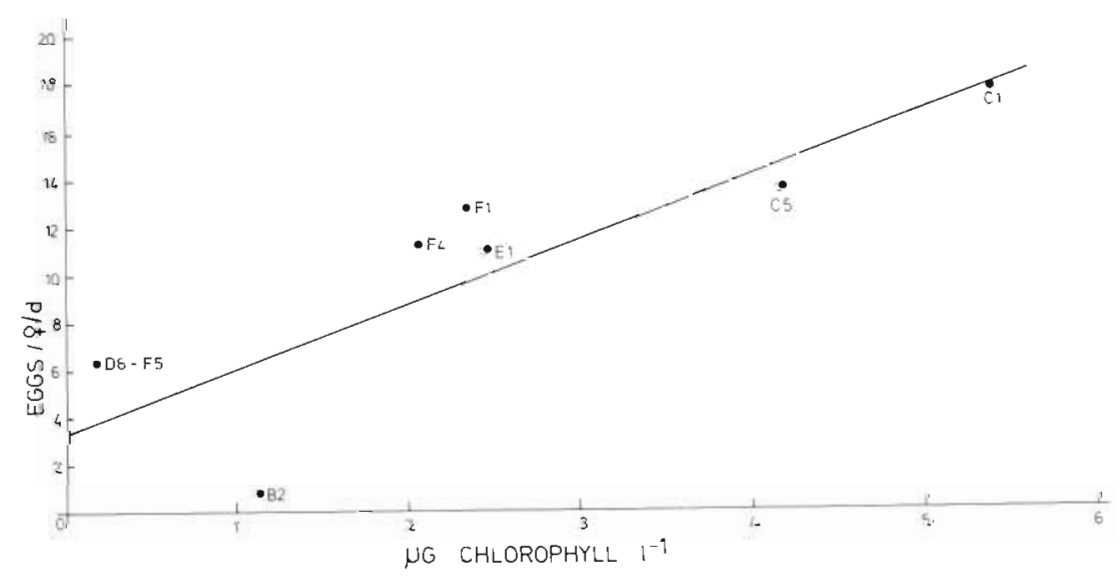

Table 2. Calanus finmarchicus. Collection data

\begin{tabular}{|lrrc|}
\hline Station & Date & $\begin{array}{c}\text { Collection } \\
\text { depth }\end{array}$ & $\begin{array}{c}\text { Depth interval for } \\
\text { fluorescence mean }\end{array}$ \\
\hline B2 & $5 \mathrm{Apr}$ & $22 \mathrm{~m}$ & $22.0-28.7 \mathrm{~m}$ \\
$\mathrm{Fl}$ & $7 \mathrm{Apr}$ & $28 \mathrm{~m}$ & $25.3-30.8 \mathrm{~m}$ \\
$\mathrm{El}$ & $8 \mathrm{Apr}$ & $16 \mathrm{~m}$ & $13.8-18.0 \mathrm{~m}$ \\
$\mathrm{Cl}$ & $10 \mathrm{Apr}$ & $7 \mathrm{~m}$ & $5.9-7.8 \mathrm{~m}$ \\
D6-F5 & $11 \mathrm{Apr}$ & $12 \mathrm{~m}$ & $8.2-21.0 \mathrm{~m}$ \\
F4 & $12 \mathrm{Apr}$ & $11 \mathrm{~m}$ & $10.5-12.5 \mathrm{~m}$ \\
C5 & $13 \mathrm{Apr}$ & $10 \mathrm{~m}$ & $8.2-13.8 \mathrm{~m}$ \\
- Station located midway between Stn D6 and F5 \\
\hline
\end{tabular}

associated with patches of high salinity water. Over the entire region of stratification, dense pycnocline populations of phytoplankton (chl a up to $>20 \mu \mathrm{g} \mathrm{l}^{-1}$ ) were observed. This pattern apparently occurs at least intermittently throughout the season in this area. Dahl
\& Danielssen (1981), in a study covering the first 6 mo of 1980 , recorded $32 \mu \mathrm{g}^{-i}$ chlorophyll along the pycnocline north-northwest of Hirtshals on 8 April. This was, by far, the highest concentration of chlorophyll recorded in their survey. Similarly, Pingree et al. (1982) reported chlorophyll a concentrations of up to $30 \mu \mathrm{g} \mathrm{l}^{-1}$ in the pycnocline population in the same general area during August 1981.

The pattern of chlorophyll distribution in surface waters near the front and, in particular, the appearance of a chlorophyll patch in surface waters at Stn D6 between the 8 th and 10 th of April suggested that mixing of the pycnocline algal population into surface waters may be occurring in this zone. This assertion is supported by the fact that the chlorophyll patch at Stn D6 was located in water of lower temperature than that previously observed at this station which may suggest that the patch had its origin in the subsurface waters to the east of the front. 
The nutrient data (Fig. 5) and easterly winds prior to this cruise suggest that the high salinity patches observed along the Swedish coast (particularly during the first half of the cruise) may have resulted from 'upwelling'. The assimilation indices (Fig, 6) recorded suggest that phytoplankton in the surface waters of these 'upwelling' regions and in the vicinity of the front were in better physiological condition and more efficient in their phytosynthesis than those in surrounding waters.

Calculated primary production rates reflect these elevated assimilation indices and the high standing stock of chlorophyll (phytoplankton) in the front and upwelling regions, in that production appears markedly higher in these areas. It should be noted, however, that on April 8 when primary production measurements were carried out through the North Sea/ Skagerrak-Kattegat front, there was a distinct boundary between the 2 water masses and only at 1 frontal station were high surface concentrations of chlorophyll a recorded. This chlorophyll distribution resulted in a very high calculated daily primary production rate in the immediate vicinity of the front.

Although primary production rates were not determined on the other sampling dates, the chlorophyll distribution pattern on these days suggested that elevated primary production would most probably be occurring at a number of the stations in the frontal region. Thus, the result reported here, suggesting high production only in the immediate vicinity of the front, is most likely simply a reflection of the chlorophyll distribution on the sampling day. Taken as a whole, the results suggest that elevated primary production rates may occur intermittently over this highly dynamic frontal region.

This observation may be particularly relevant in relation to the toxic blooms of the dinoflagellate Gyrodinium aureolum, that occasionally occur in Skagerrak waters. In early September 1981, Dahl et al. (1982) observed a population of this alga at a depth of 20 to $30 \mathrm{~m}$ approximately $18 \mathrm{~km}$ north-northwest of Hirtshals on the Danish coast. No salinity data are given in their report but this is a region that often experiences a strongly stratified water column with respect to salinity and which lies within the frontal mixing region observed in this study. At the time of that study, there was apparently no $G$. aureolum observed in surface waters but some 3 wk later a serious 'bloom' was underway along the Norwegian coast and extending up to $30 \mathrm{~km}$ offshore (Dahl et al. 1982) Richardson \& Kullenberg (1984) have pointed out that the serious coastal blooms of this alga in Scandinavian waters have all occurred at salinities of between 25 and $34 \%$ - corresponding well to those in the frontal mixing area. Southwest of the English Channel, blooms of this alga have been shown to develop in association with a thermal front (Holligan 1979). Thus, there are grounds to indict this front in connection with algal blooms in surrounding waters. A better understanding of the hydrographic and biological processes occurring in the vicinity of this front especially during spring and summer months could well improve our ability to predict when such blooms are likely to occur and why they fail to occur in some years despite the presence of the alga in the area.

Although a marked association between algal distribution and phytosynthesis and the front/upwelling regions can be seen, the same is not obvious in the copepod nauplii/egg distributions. There were clearly more copepod nauplii and eggs associated with the upper 15 to $20 \mathrm{~m}$ of the Skagerrak and Kattegat than with the bottom waters of these regions or the North Sea water. Beyond this, it is difficult to see distinct patterns in microzooplankton distributions. However, there does seem to be an indication that concentrations of copepod eggs and nauplii may be elevated in and/or over dense pycnocline patches of chlorophyll $a$. This finding is similar to results found during a study of zooplankton distribution in relation to upwelling events (Paffenhöfer et al. 1984) in which zooplankton maxima occurred in association with phytoplankton biomass maxima and not necessarily with peaks in primary production.

There is, unfortunately, no data relating to distribution of adult copepods for this cruise. Thus, we cannot judge to what degree the apparent peaks in copepod nauplii/egg concentration near dense chlorophyll patches are related to greater numbers of egg-laying females in these areas and/or to increased production. However, there is at least some evidence for increased production in the data for Calanus finmarchicus where egg production rate was found to be positively correlated with chlorophyll content of the water mass from which the experimental animals were collected.

The failure to observe a peak in copepod nauplii at the front in this study despite apparently elevated surface chlorophyll concentrations in the frontal region contrasts with findings of Floodgate et al. (1981) who presented data suggesting a possible peak in copepod concentrations near a salinity front in Liverpool Bay in comparison to surrounding waters. On the other hand, Holligan et al. (1984) found no increase in copepod nauplii concentrations at the thermal front in the western English Channel. They suggested that the presence of the bloom-forming dinoflagellate Gyrodinium aureolum in surface waters near the front may explain their failure to observe large numbers of nauplii in the frontal region. Although an entirely different type of front was under investigation, results of a study conducted by Kahru et al. (1984) in the Gotland Basin 
parallel those found here in that assimilation number and potential primary production peak in the immediate vicinity of the front whereas the peak in copepod numbers occurred at some distance from the front.

In the study reported here, the physical processes occurring near the North Sea/Skagerrak-Kattegat front and in 'upwelling' regions near the Swedish coast appear to have had a direct effect on phytoplankton distributions and production. This effect was not so pronounced on the zooplankton distribution and activity in these areas during the study period. However, the time series data collected indicate that chlorophyll distribution patterns especially in the frontal area changed dramatically over short (2 to $3 \mathrm{~d}$ ) time periods and it may be that the zooplankton populations in the area were unable to respond to changes in the phytoplankton population and distribution occurring on such a rapid time scale. In at least 1 other study (Christensen et al. 1985) a marked increase in copepod egg production rates was recorded near a thermal front off the northeast Scottish coast. Thus, further study is clearly needed to establish the influence of frontal processes on secondary production in this and other frontal regions.

Acknowledgements. I am grateful to Dr. T. Kiørboe for making the zooplankton data avialable to me. S. Sorensen and $P$. Iversen undertook the light and nutrient measurements, respectively, and K. Nygarrd developed the programs for data analysis.

\section{LITERATURE CITED}

Beardall, J., Foster, P., Voltolina, D., Savidge, G. (1982). Observations on the surface water characteristics in the western Irish Sea: July 1977. Estuar. coast. Shelf Sci. 14 $589-598$

Christensen, V., Dahl, E., Danielssen, D. S., Hundahl, H. Kiørboe, T., Kullenberg, G. (1983). A combined fish larval phytoplankton, and oceanographic survey in the Skagerrak and the Kattegat in April 1983. Coun. Meet. int. Com. Explor. Sea C.M.-ICES/L: 26

Christensen, V., Heath, M., Kiørboe, T., Munk, P., Paulsen H., Richardson, K. (1985). Investigations on the relationship of herring larvae, plankton production and hydrography at Aberdeen Bank, Buchan area, September 1984 Coun. Meet. int. Coun. Explor. Sea C.M.-ICES/L: 23

Dahl, E., Danielssen, D. S. (1981). Hydrography, nutrients and phytoplankton in the Skagerrak along the section Torungen-Hirtshals, January-June 1980. In: Særte, R. Mork, M. (ed.) The Norwegian Coastal Current. Univ Bergen, p. 294-310

Dahl, E., Danielssen, D. S., Bøhle, B. (1982). Mass occurrence of Gyrodinium aureolum Hulburt and fish mortality along the southern coast of Norway in September-October 1981. Flødevigen Rapportserie No. 4

Floodgate, G. D., Fogg, G. E., Jones, D. A., Lochte, K., Turley, C. M. (1981). Microbiological and zooplankton activity at a front in Liverpool Bay. Nature, Lond. 290: 133-136

Fournier, R. O. (1978). Biological aspects of Nova Scotian shelfbreak fronts. In: Bowman, M. J., Esaias, W. E. (ed.)
Oceanic fronts in coastal processes. Springer-Verlag, New York, p. 69-77

Fournier, R. O., Marra, J., Bohrer, R., Van Det, M. (1977) Plankton dynamics and nutrient enrichment of the Scotian shelf. J. Fish. Res. Bd Can. 34: 1001-1018

Fournier, R. O., Van Det M., Wilson, J. S., Hargreaves, N. B. (1979). Influence of the shelf-break front off Nova Scotia on phytoplankton standing stock in winter. J. Fish. Res. Bd Can. 36: 1228-1237

Foyn, L., Iversen, S. A., Lahn-Johannessen, J., Ljoen, R. (1978). Investigations in the North Sea, Skagerrak and Kattegat during 1977. Fisk. Havet 4: 1-47 (in Norwegian)

Grasshoff, K. (1976). Methods of seawater analysis. Verlag Chemie, Weinheim, New York

Holligan, P. M. (1979). Dinoflagellate blooms associated with tidal fronts around the British Isles. In: Taylor, D. L., Seliger, H. H. (ed.) Toxic dinoflagellate blooms. Elsevier/ North Holland, New York, p. 249-256

Holligan, P. M., Harbour, D. S. (1976). The vertical distribution and succession of phytoplankton in the western English Channel. J. mar. biol. Assoc. U.K. 57: 1075-1093

Holligan, P. M., Harris, R. P., Newell, R. C., Harbour, D. S., Head, R. N., Linley, E. A. S., Lucas, M. I., Trantor, P. R. G. Weekley, C. M. (1984). Vertical distribution and partitioning of organic carbon in mixed, frontal and stratified waters of the English Channel. Mar. Ecol. Prog. Ser. 14 $111-127$

Hundahl, H., Holck, J. (1980). A new in situ fluorometer for detection of Rhodamine B and chlorophyll. Report No. 42, Inst. of Physical Oceanography, Univ. of Copenhagen, p. 145-154

Kahru, M., Elken, J., Kotta, I., Simm, M., Vilbaste, K. (1984). Plankton distributions and processes across a front in the open Baltic Sea. Mar Ecol. Prog. Ser. 20: 101-111

Kiørboe, T., Møhlenberg, F., Riisgård, H.-U. (1985). In situ teeding rates of planktonic copepods: a comparison of four methods. J. exp mar Biol. Ecol. 88: 67-81

Mills, E. L., Fournier, R. O. (1979). Fish production and the marine ecosystem of the Scotian shelf, Eastern Canada. Mar. Biol. 54: 101-108

Paffenhöfer, G.-A., Webster, B. T., Nicholas, W D. (1984). Zooplankton abundance in relation to state and type of intrusions onto the southeastern United States shelf during summer J. mar. Res. 42: 995-1017

Pingree, R. D., Holligan, P. M., Mardell, G. T., Harris, R. P. (1982). Vertical distribution of plankton in the Skagerrak in relation to doming of the seasonal thermocline. Cont. Shelf Res. 1 (2): 209-219

Pingree, R. D., Pugh, P, R., Holligan, P. M., Forster, G. R (1975). Summer phytoplankton blooms and red tides along tidal fronts in the approaches to the English Channel. Nature, Lond. 258: 672-677

Richardson, K., Kiørboe, T., Christensen, V. (1984). Phyto-/ zooplankton distribution and activity in the North Sea/ Skagerrak-Kattegat frontal area in April 1984. Coun. Meet. int. Coun. Explor. Sea C.M.-ICES/L: 16

Richardson, K., Kullenberg, G. (1984). Physical and biological interactions leading to plankton blooms: A review of Gyrodinium aureolum blooms in Scandinavian waters. Int. Coun. Explor Sea ICES A2 (Special meeting on the causes, dynamics and effects of exceptional marine blooms and related events)

Richardson, K., Lavin-Peregrina, M. F., Mitchelson, E. G., Simpson, J. H. (1985). Seasonal distribution of chlorophyll $a$ in relation to physical structure in the Western Irish Sea. Oceanologica Acta 8 (1): 77-86

Savidge, G. (1976). A preliminary study of the distribution of 
chlorophyll $a$ in the vicinity of fronts in the Celtic and Western Irish Sea. Estuar. coast. mar. Sci. 4: 617-625

Seliger, H. H., McKinley, K. R., Biggley, W. H., Rivkin, R. B. Aspdern, K. R. H. (1981). Phytoplankton patchiness and frontal regions. Mar. Biol. 61: 119-131

Simpson, J. H., Edelsten, D. J., Edwards, A., Morris, N. C. G., Tett, P. B. (1978). The Islay front: physical structure and phytoplankton distribution. Estuar. coast. mar. Sci. 9: 713-726

Simpson, J. H., Tett, P. B., Argote-Espinoza, M. L., Edwards, A., Jones, K. J., Savidge, G. (1982). Mixing and phyto- plankton growth around an island in a stratified sea. Cont Shelf. Res. 1: 15-31

Strickland, J. D. H., Parsons, T R. (1972). A practical handbook of seawater analysis. Bull. Fish. Res. Bd Can. 167 $1-310$

Svansson, A. (1975). Physical and chemical oceanography of the Skagerrak and the Kattegat. I. Open Sea Conditions Fish Bd. Sweden. Inst. of Mar. Res., Uddevalla. Report No. 1, p. 1-88

Tranter, D. J. (ed.) (1968). Zooplankton sampling. Monographs on oceanographic methodology. UNESCO, p. $1-174$

This paper was submitted to the editor; it was accepted for printing on August 6, 1985 